\title{
Adjourned Discussion
}

\section{General Sir Frederick Stephenson In the Chair G.C.B.}

To cite this article: General Sir Frederick Stephenson In the Chair G.C.B. (1889)

Adjourned Discussion, Royal United Services Institution. Journal, 33:147, 178-202, DOI:

10.1080/03071848909441233

To link to this article: http://dx.doi.org/10.1080/03071848909441233

\section{Published online: 12 Nov 2009.}

Submit your article to this journal $\pi$

Џلl Article views: 1

Q View related articles $\sqsubset$ 
whaterer about our having the commnnd of the sea, as far as such a thing is possible to be made mathematically certain. Sir I.othian Nicholson thinks that it was to be regrelted that such a puper ns ddmiral Colorob's had been read, because the I'ress will publish it; and the public will only hear ono side of the question, because the paper will bo giren in full, and the discussion will be condensed. But the rers raison d'elre of demiral Columb's paper, from its first paragraph, is that certain statements had been made in a former paper, written by an Officer on a detail of ore branch of military science. riz., arming batterics with quick-firing guns. A great part of that faper went into the fundamentul rules upon which the whole armed force of this country are to be employed in wnr. I r.gself, when'I heard the arguments, thought them bcyond measure unsound, and to indieato that that Officer was not rery nell acquainted with the history of tho wars which this country lus been engaged in during the last tro centuries; and I rers much regretted that it should go forth from this Institution without some reply; but I felt that we were then discussing quick-firing guns in bafteries. But the opinions expressed in that paper liare gone forth to the countrs, and I think it was quile right that thes should therefore be discussed here. Now, with regaril to the ralue of the past history of the Nary as a guide to the future, we should recollect that, included in naral histors, the Amms has got a rery glorious histors. I should liko to trace that glorious history of the A rmy through its anmals. I rould go back as far as the war of the Spanish succrssion, which rendercd immortal the name of Marlbrrough. There was an English army on foreign soil. How was that army supplied? That army mas supplied bicnuso we had obtained the cornmand of the eea at the Battle of La Hogue. Go on to the next great war-the Seren Years' War. The brillinat exploit of General Wolfe, which enderl in the capture of Quebec, was rendercl possible by.our haring the command of the scas, to maintain which large Acets blockaded Brest and Toulon. The Batrlo of Plasss was mon by Clire; but tlis nould nerre hare been fought if ddmiral Wiatson bad not been there with his flect to protect and co-operato with the army. In the next war the great operntion of the Army was the defence of Gibraltar, which Ailmiral Colomb has referred to. Look at the wars of Napoleon. Thic brillinnt expedition to Egspt was only possible on sccount of the command of the scas haring been preriously obtained by the Battle of the Nile. I need not dxell on the Peninsular War, which ras renderct possible by the absolute command of the eea haring been confirmed at Trafalgar. Thicse are facts in whirh I think our friends of the Army must recognize that those brilliant achierements which hare distinguished their Service so grently for the last 200 years hare been possible because we held the cominand of the sea.

$$
\text { [The discassion was then adjourned to 4th M[arch.] }
$$

Mondng, March 4.

\section{Adjoursed Discussion.}

\section{Gexeral Sir PREDERICK STEPHFNSON, G.C.B., in the Chnir.}

Lieutenant-General Sir Gersld Grshay, V.C., G.C.JI.G., K.C.B. : Sir Frederick Steplicnson and gentlemen, whatever may be the merits of Admiral Coloub's interesting paper as a samplc of sound reasoning, there can be no question as to its ability, and as to its haring proved nost raluable in eliciting expressions of opinion from competent Ollicers of both Serriecs, though I think the public will naturally attach more importance to the opinion of a naral Officer who differs from Admiral Colomb, as all have niore or less hitherto, than to that of a military Officer like migself. I think that all who wish well to the defences of the countrg, nnd I include the gallunt Ailmiril, altliough an adrersary, hare reason to feel grateful to Lord Carnarron for the admiribly clear statement be made at this Institution at the prerious mecting, and that we may feel some confidence in the decision of a Commission of which he 
was Prezident. Although I disagreo utterly with the gallant Adiniral's concluoions, I cannot resist a certain fecling of adniration for his perfect confidence in the power of our Ninvs to keep the command of the sea under all circumstances as its indefe:lsible riglit and attribute. This, howercr, eccus to me rery unch as if a Getreral stirtel with a plan of campaign-the pluruse is ruther in batl odlour just now - the suece'siful esecution of which depended on his winning crers battle. "Rule Hrit:mulit" is a rery fine song and we have often joined in the chorus, but when we meet in this Institution we ought to put scutiment on one side anl look facts soberly in the face. I should like to hear from Adminal Colomb what this idcal commanel of tho seis neans under present conditions, and according to his theory of defence by a moring navg. What fects would be required to secure our consts, communications, and commerce against the greatest probalule or possible combination of naral Powers? What would it me:an in money outlay nnd annual exprnditure? Finally, is it practicable or only a dream? We know on the best authority that at present we should be decidedly inferior to n combination of two greas naral Powers; nerertleeJess, Adnuiral Colomb bises his whole theory of limperial defence on our being everywhere superior at eca. With this assumption of conditions which do not crist, Adiniral Colomb regards the fortifieation of our arscuals, dockynrds, and coaling: stittions as utunecessary, for, fur from being factors of etrength to our nitval poner, lley weaken it by taking money which ought to be expended on thu flects. In shurt, the Nary is to undertake the diefence of the Unifed Kinigilom atul of our lines of coumunication and commerce, and it is too confilent in its insincible power, an:curding to Admirul Colomb, to uced nuy reserre, so that, 11 i cletrly stated by General Ershine, all our liusd defences may be dismantled and our neserre forces of militiab and voluntecrs disbanded. I was glad to bear this conlition franhly adopted by Cuptain Penrose Fitzgerald, R.N., though the gallint Ollicer's statement wus reccircd as an crecl]ent joke, as it cmphasized what Sir $\mathrm{I}$. Nicholson callet a " reduetio ad alsurdum," though I cannot say if this was the point Sir I othian had in his mind. We mas be on the cre of a rery critical epoch in our uational histors, and the unind of the country, and therefore of l'arliament, scems at last aw:ilening to the danirerous state of our defences, nud we nust consider the probable elfect on the public mind when it is known that an eniuent naral Offecr, speaking with weight and authority on the naral armaments of the Empirc, gives it out as his deliberato opinion that our polics of defence for the last thirty years bos been utterly wrong. I mas be ruistukea, and sinecrely hope I am, but I cannot help fearing that this paper mas do larm by obstrucling the ciforts of patriotic stateswenliko Iord Carnarron, who ardently desire to bring the pre'sure of public opiniun to bear on the Gorernment to complete the clefenecs of our ports aud cuuling stations. When the puhlic secs its naral and enilitary cxperts at logererheads on the first principles of defence, it does not care to go into the uncrits of the argunents; tho effect on the British taxpayer is to make him button up his poilets. I trust, howerer, that Joln Bull will, on this oceasion, leep his ejes ofen and sec what the argumeuts of the gallant Admiral lead to. 'Tle areruge English citizen reads his dally paper, but does not hare a rery clear conception what a coaling station mcins, and if dduniral Culomb tells lim it is quite unnecessary to fortify it he mas sas, "Well, the Admiral must lnow more about naral wants than a unere militars wan, thereforolet us sare the mones." If, howerer, the same man is told that to follow out the Admiral's riens, tho citizen amy, of rhich he is justly proud to be a nuenber, unust be distanded as usclcss, he gires up his faith in the filuiral at once, at least on this question. I haro ovls tiune to touch on a fow points in delwiral Colonb's paper, and ha lias fronkly invited the screrest criticism. I was be allowed to express as. tunishnent that viith to bad a casc so good a paper has bien produced. The ddiniral las giren us leare to fire amaj, and no doubt he will stand heavier shot than I can bring to bear against him. I trust, howerer, that nothing I waj say will be hell incongistent with the respect I feel towards the Adwiral and the courtesy which is his due. It is surels a somerhat. strange argument aevinst the fortifiestion of a port that once you begin jou don't know when to stop, thist as ddmiral Colonb's. naral friend, of whom I desire to epeak in terms of the ul most respect, puts it, "thero is nothing between a light batters and a first class fortress." It would alinost seen as if the two gallant Odicers, in their desire to run down the fortification of ports, 
had wandered somewhat into the hazs regions of philosophy, and started a new thicurs of crolution anulogous to that of tho derclopinent of epecics, by which wo leurn thast ann has, by iuperceptible gradations, been crolred out of a mollusc. Giren n unollusc, and by process of derclopment yon mot get the man if your rait long enough; or, as here stated, given a light liniters, and in process of tines it will derelop into a first class fortrcs3. Further on, the gallant Adiniral scems troubled with a yeirning after an idcul fortifiention, and on pago $\bar{j}$ lie writes, wore, I hope, in sorrow than in anger, "No one has $y$ ct discorered or inrented a fortified port capable of maiutainiug it self for all tiune ngainst a sea attack." Certainly not. But is that is reason for nbolishing fortified ports? This is logic nith a rengennec" No fortificutions ore perfect; imporfection is undesirable; therefore hare ro for. tificutiong nt all." I am afraid that cren Ier Majesty's ships and guns, down to our sworls and biayonets, are not perfuet, yet we inust continue to use them. Admiral Colomb tells us that "fortification of ports is but an inefficient gubstitute for their narnl defence." Norr I beg to denur to this statement altogether, as fied fortific.ltions nerer call be regardel $n 3$ a $*$ ubstitute, efficient or inclicient, for unoring navn! defence, which is wibat the Aduniral me:ans. On this mistalien preniss the Aduniral infers that ns we propose a naral increase we should logically propose a fortification decreasc. I kould, if I might do so without oflence, be" to sughest the prefr "il" before "logicalls." The gillant Alimiral frequently nppcals to logic, but he will cxcuse me for saying that he is not always lopical in his statements. Thus, at onc part of his puper he stutes that he draws " a distinction betrecn the defence of the port ngainst nttack and the defence of the communications of the port;" Jet, further on, in the eases of Plgmonth, Singipore, s.c., he falls foul of the fortifications fur not protecting the communication, which is slltrely no duty of theirs. Ue will not allow that firc French battle-ships lying of Plynouth could bombard the Docksard, eren if it were totally unprotected with fortifications, because of lise presence of ten English battle-shijps at lirest, 200 miles off : Jet in another pirt of his papes lic admits tliat Malta Jockyarl, supposing it nere undefended, miglit be got at and destruycu in a few hours bs a couple of dsehing cruizers. Onc remnrknble feature in this, noled by Captnin Fitzgerald, is that the Admiml secms indifferent. whether $\mathrm{Pl}$ smouth is dest rored or not. On this point Captain Fitzgemld has already bombarded the gallant Admirul, and therefore $I$ will say no nore. II is compelled to adnit that, " but for her fortifications Cibraltar would not now be our posacssion," Jet goes on to assert that under present conditions they are useless. 'This secais to me playing fast and loosc with the historical argument. Surely if naral history teaches us angthing it is that our acets wero constantls losing local cummand and regaining it. If these periods of lnss were short, the gorts, if fortiged, held out ; if long, they fell ; and by tlic ddmiral's statentent tho periods for relief of blockided ports would be much shorter with stcan, so that fortificd ports rould liare better cliances of holding out. 'The gullant Admiral has en. dcaroured to slion that the fortifications of Singapore are uscleis. Captain Stone, followed by Captain Fitzgerald, hare ably shown the fallacy of his reasoning, but I feel on eafer ground in quoting the opinion of Adwiral Sir Vescy Hanilton, who stated in Maj last, at a lecture giren by Admiral Colomb, "The great thing I had to fear when I wus in China mas this, that until the gung for the port s were ecot out the Ninvy bad to defcal the ports of Singapore and JIong Kong. Now that Singaporc aud Hong Kong hare got their guns and are defended, the Admiral in Chins is left frec to defend his commerce." No more nutloritatire stateuent is possible. It comes from an eminent naval Oflicer, with all the wcight of authority due to experience and the responsibility of cummund. He states distinetly that when ports are defended the Nary is frec to protect the conmerce, and 1 rould wial that whererer ddmiral Colonib's puper is read, this plain tale of Sir Vescy IIruilton's should be read al so. One word more as regurde the historical argument. Iile Sir Irothian Nicholson, I caunot help fen ring that the ceperience of former Javal wars is an unsafo guicle for the future, aecl much th I admire that spirit of coufdence in the British tar, which has carried our flan rictorious orer erers sea, I cannot lelp secing sone danger in it. Tue storage nnd protection of motire power unust now control naral strategs, and $I$ leare it to naral Oficers to tell what a complcte repolution atcam hes caused in naral tactics. History tollo us that orerwecning 
confidence has frequently led to rational disnoter in another generation. The glory of Fredericl the Grest was dearly puid for at Jena, and that of Nipoleon the First ut sedav. Before I ait dowe I wish to ald $\mathrm{ms}$ protest against thu notion which this paper rather tends to encourage, that there is ally spirit of antanonism or un. friendly riralrs between the Arws und the Nary ("No, no "), that the Army should he represented as in soine was supplanting and robbing the senior Service. I do not adnit that ans zuch fecling exiets in the surrice to which I liare the honour to belong. We aro all proud of our Nayy : we reard it as our first and most impor. t:aut line of defence. My experience lias been that when we arcecring together we do so heartily, and without jeulousy or rivalry, worbing tonctler ns good comrades for the honour of Old Englued, and our wish, as that of all true Englishmen, is to Ece our Nary strong, and, if possible, mistress of the sers as of old.

Sir Joux Conosu, fi.C.JI.G., JI.P.: In the few minutes which are nllotted to cach spealer it is really rers dificult to cover the grouml und at the same time: aroid being misunderstood. I thiuk the best hope of accomplishing the duty of discussing, without being misunderstood, in so short a time, may be to find sunc puint on which we are all agried. I beliere that we ure nll agrecel, ut all crents, upon thiz, that the title of the paper is the "The Relations between Local Fortifications and a Moring Nirg." Now, of course, we maj straj rery far awisy from that ; but there is another point upon which I thiuk wo are all arned, soldiers, sailors, cirilians, und all alike, that our moring nary must be sufficicnt to do its work. Then ury next point is, what is that work? I think it mas be thus shortly described-that its work is to paralyzo the pover of a hostile moring mass to do us great and ecrious mischief. 'l'herefore the main issue raised by the paper appears to me to be this, lo unclearour to elicit discussion, and, if pussible, to ecientificalls detcruine what nre the relutious of our local fortifications to a lostile Aect, the power of which to do us great and ecrious mischicf has nlready been paralgzed by the sulticiency and efliciency of our moring nasy? Before dealing with the paper itsclf I would eay a few words in attempting to criticize the criticisms that hare been offered. In the Gest place, it is pointed out by our gallant friend General Frskine, that if we commund the sea cert:in things will happen; but I take comnanding the eca to mean that our woving nars is able to do its work, and if from the fact that tlie Nary is uble to do its work, invasion is inpossible, we caunot help it; und if public opinion, as the General stid, won't beliere it, eren if true, we cannot help, it. What we really lave to do in this Institution is to endearour to get at the facts and the truth. Then our esecllent friend Sir Joothian Nicholson drex a vers gloomy picture of the result of our woring unvy doing its work; in otber words, commanding the sen; he pictured the wilitia and rolunteers twidhliug their thumbs. That wo cunvot belp. I must agrec with him cntirely in this, thut our solclicrs in this great Empirc uust do their work, but I usscrt thes cannot do their work unless the Nary dues its work first in coutusnding the sca. He said that as a militars man ho could gire no opinion upon narul affars, and he nest, rery kindly and goot-naturedly aud wost courtcously, hitched up his trouscrs, metaphoricully speraling, proceded to take the resther gauge of the weeting and to pronounce a naval dictum, which he afterwards cxplsined-that the Nary had no history. Well, I understood him perfectle to mein thit, in his opivion, we could not now rely upon history to instruct ue with regird to modern maral war. I am sure he won't tako it pereonal if I renture to think, in my own humble way, that lie is entirely and absolutely wrong in that sense. I 835 , Sir, that steam lias no ware obliterated the teachings of histors in the Narg than it has in the drung, and that the influence of stean in cxtendirg the ares and possibilities of military warfure in land operations is quite as griat 35 the infucnec of stcaw on sca opcrations. In obliterating the tenching of naral histors, is he therefore prepared to obliterate military histors? Now I cowe to the nest epealer, rlo ratber surpiiscd unc, Calptiain Stone, who said ho did not adrocate locking up our drmy in detachenents all orer the world, but he did adrocate all those places being iupregnable. I confess I nm puzzled at this declaration of the spealer. IIow can you get de. ta:lied iumpreguable local positions without detached militurs forces? And I s.dy that thes will be locked up forces if we do not command the sea. The neit mutter I come to is this. He indicated in ratber a depreciating way that we 
must abondon the attempt to command the eca, for he eaid the conmand of the sea หus a rery large order. Well, Sir, the Britisls position in the rorld is itsclf a luric order and makes rers large demands, and if we are to preserte our position in the world tre unust not shirl faring the demands that our position nakes upon us. 'Then wo had my cheerful friend Captain I'enrose Fitzgerald, who plaintircly informed the soldiers that in war thes would not be in the hunt. I heartily agrec with him, if Captain Stone's view be adopted, because ther will havo no horses lanlezs the Nary coomands the feis. Sot a strummer boy can be morcl. All I can say is, that the Nars is the corcring force for the transport of the Arms. Now, I come for one anoment to a speceh that was listened to, as it ougbt to be listened to, coining from the source it did-from Lord Carnarron, and I confess that I thouglit it dealt more with the epecial question subinitted to bin in 1879 than with the question we are discussing here. I think it was unfortunate that a noble lord of his cminence should hare publicly nnnounced in this theutre that this Fupire had in war only tro things to do: one being to protect our own shores-the sliores of these islands, and the ot licr the protection of conmerce. I protest against ung Englisliman learing out of necount the duties and responsibilitics of this Fopire with regard to her fronticrs over sea, and our great Indian Enpire. Iord Carmarron, in concluding, apologetically remarled that if my brother's and my own riews preruiled, we sliould reguire an enormous flect. I slionld like to read to the unceting what Lord Carmarron's opinions were, as Chairuman of the Commission, as eridenced by the Report of th:it Royal Couruissiou of 1879 . Jere is the Report. It speals of "the necessity of minintaining, not only a fleet suflicient in number and in jower to gire alsolute security to the sca-board of the United hingdom, but also to pro. ride fast vesscls, so stationed ns to be ready at the commencenent of hostilitits 10 deal with the enemy's ships in more distint scas. We, the Commissioners, fecl bound to express our opinion, on looking to the uction of ot lier count ries, that the strength of the Nary stiould be increased with as little delas as possible." I call the attention of the mecting to the rords "absoluto security" lis nasal means. Lord Carmarron, in 1870, as licud of that Commision, demanded is Acet subicient to provide "absolule sccurity" for our eliores and for all our maritime rants. I will onle say that, to tale tlie rercrse side of the jicture, if you do not proride that Acct, this, to $\mathrm{m}_{\mathrm{j}}$ nind, is ceituinly true-this Empire is gone, and the worul effect alone of the fact that your cowmand of the etal is gone will extinguish all margin of possible jrofit, which means the closing of your factories, the ehuttin's up of jour industries, the cessation of the operations of jour Stock Ficlianges, your shops, and your counting louses. I say distinctly, in my humble judgucnt, it conses to this, that if your moring nary is nut able to do its worl, the position of sone forty millions of people in these islands will be the position of 50 mans rats in a trip. I ogrec with my brother in his main contention, nud I think his juper was called for, becausc 1 ain oue of those that for many jears have felt that while on the one liand in the pist ure were absolutels neglecting to give nny local protection at all to our naval stores at different points, on the ot her hand, we hare now swung round, and we are now too nuch tempeted to speud too inuch mones on, and to orer-do local clciences. I an not preplared to go quite so fur as his paper appears to me to indicate, but I can quito conceivc, pulting mysclf in bis position, and looking at the necesities of tho time, that really in urter to raisc a distinct aud clear discussion you nould bare to push your allvinced posts of argument perlijps a little further than jou might otherwise be inclined to do. Therefore 1 eay, that while I ugrec absolutely in his main contcittion, he does go a little further than I ms sclf am prepared to go. If we exclude nll clsc but actual war-ships from the conditions of war I thint I niglit be prepured to necept nluost an crtreme view; but I am not prepared to exclude from the conditions of enaritime war all elso but war-ships. I look at local neans of defence, at naral uascs; and coal depoits, :I neccisary to prercut the destruction of the docks, coals, and atores of our war and wercantile ships bj raiders, because I think raiders are in this caso jour primary danger, and also the facility that stean gires for the rapid, certain, and Eudden moresnent of troops from mercantile ports. I hare eaid already I do not think stcan has altered tue conditions of naval straterg, but I thint it has extended their application; and what it bas done, aud whut $I$ think is the nost scrious 
modern clement affecting our defensire position is this, that it has opened up nud sidded to the problem of maritime defence, aud has increased the puner of impro. viscd attack outside noring war narics. We, I think, of all nations must recognize than fuct. I will tuke the case of Singapore, and I will point out that while I quite agree with the contention of the lecturer that it is useless to defend Singipore unless jou are prepared to defend the local waters around it, I say that taling his illustration of the sesure Singapore, and the colliers being captured outside, that. is jot so bad a position as the cosls in Singinporo being dest rosed and the conls outsicle being captured nlso. I am bound also, in dealing with this question, to mention one illustrition of histors which I direlt upon miny scars ago, nanicls, the cise of the Mauritius. The Mnuritius was held by the Fruch years after llic lattle of 'Trafulgar. It was found that it was a hornct's nest from which prirutcers issued, and it was determined by the Gorernor. Aeneral of Indis that this unust eciste ats if wiss ruining trade. We realls commanded tho sca, aud the Dule of Wellington, then Iord Wellesley, was sent to Ceylon with a laige force of troops for the pur. pose of scizing the Mauritius. Admiral hasner, I think, conmanded the fleet to casce the adrance of theso troops on the Nauritius. A difference between the Admirnl, who declined to go, aud the General, who was ordered to go, bru:ight matters to such a state that they had to abandon the expedition altugether, because the Adutirsl did not agree witl it. So the ruination of our commeree in that seds went on; but later the nivnl authorities in the district found they must root this place out, and they ent a purely naval attuck ogainse the JInuritius, with a reault that was terribly disastrous. lears afterwards we made a combined military and naral altack; we took the place. I point that out as showing that in all these matters in connection with naral bas's you como at last to a combination between the Army and the Nivy. 'That is very briclly my rier. I cunnot renture to detain jou much longer, but looking nt the dutics and responsibilitics of our whole Empire, and secing what the action of the British public is, and that I'urliament will not open its cyes, we are bound to fultil the primary condition of our existence, that is to mainlain tho command of the scas; but linring that, we are not to run awar with the illea that we hare then discharged all our duties and obligations. What i um most concerned in disputing is the eragigerated proportions of the modern doctrine of lucal fortifieations for the release of vur llect. I think our true safety lies in this: that our dxcks, stores, cosls, and offings must bo loeally securecl against raiding utturks, that our Flcet must conmand the sea by being strong enough to jisralyze tho power of hostile war llects, and thus to secure the release of our Army for defence of our fronticrs abroal and for descent on the euems's cousts.

Major War.er, R.E.: I shall be glad to be allowed to join in the congratulations to the lecturer for his rery uble puper-a proper, in fact, so uble and so clerer thiat it has almost persuaded Ailmiml colomb himself against his better judgment. I will read the two last lines of Admirnl Colomb's lecture, in mhich he snjs: "It is a mere ivstinct with me which udmits light batteries at. the entranec of our ports. I cammot, when I face it, reconcile their existence to um reason." In his lerture Adimiral Colomb has constructed a lecri logicul weapon for the orerthrow of fortificustions; but he hats not convineed us. In his last lines he acinits light batterjes for ti.c defence of counnerial purts. I think that he his written two lines 100 mung in his paper. In a prerious page Admial Colowb sist there is not]jing bet ween a light batters and a first-class fortress; so that we are to lare a first-clitss fortress for the defence of crery comberciai port! What, in Hearen's name, then. are we to do for the defence of Plymouth ? I think that is a point that Admiral Culomb ought to answer. Then there is auother point. General Firsibiue stated that the lecture practically amounted to this, that we must disband our land forces and disunautle our fortresses. 'The lecturer dissents from that ; but Captain Fitzgerald told us in vers forcible linguage that, "You are out of it; jou are not in the luat, you solviers. The first ehot fired by a roluntecr in anger means not the counnencement of the decidence of the Hritish Eiwpire, but its complete destruc. tion." That, I think, is letting the cat out of the bag rither as to what the incaning of the lecture is. It means practically the complnte destruction of fortilicutions - iliat we do not rant ans forticications. Now, alliongh anotlics fallant duruiral told us that we lad a glurious military histors, I do not think that that glorious 
military history will makic up to us soldiers for having loet all preecut ueefulness and all hope of future distinction, which we lare lost, if Allmiral Coloub'e lecture is sound. Captain Fitzgerald put it rery plainly. He said, "You here India; jou are a depot for Indin; but you are nothing clse; you are inerels a depót for the defence of India; that is your ouly hope, jour only rolc, for the future is to defend India." I admit that the defence of Indin is a rers glorious task, but it is not the defence of the British Empire. We hare sailcd $n$ ith the Nary all round the world; wo hare, in compnns with the Nisry, swept the ecas around the world in the acquisition of the British limpire, and 1 do not think se want to gire that Ij) sct. I think Admiral Colounb has rather createxl a structure which he then proceds to demolish, and in the ruins of this child of his own imagituation he hiss huped to bring down fortifications also. He says Captain Stone's thirri line of policy is this : "The third line of policy is that shetched by Captain Stone, if I rightly apprehend lim, nauely, the dispersil of the string all orer the world in detnched garrisons;" and then at a later purt of the lecture the dimiral gires us his own riers. IIf sngs, "lhere remaius the third function of fortitication, siamelj, the protection of the stores-the protection of the depst proper, and not the slicll of it - from the sudden ourprise and destatiction which might be effected in a short time by a small force." Iheu he goes on to say, "The original claim fur the local defence of our cusling stations did not go further than this." But supposing that Cuptain Stone did male that propusal, did propose that policy-I clid not rlearly mtch what Capt:ain Stone raid, but I beliete ho suid lie did not intend that - but supposing be did intend that as being the one line of policy, has ansbods adopted it? IIare the authuritics who are responsible for the deferec of the Eupire adopted it? Certainly not. There is no such ides. The defence that is now bcing carried out is practically a winimum defence. We hare actually adopted Aduiral Colomb's own ideinaltogether. We hisre no other idea; we drean of nothing elsc. 1 do not imsgine that the furtifications of cosling stations arc to go atalking orer the sea nud contending with the enems's cruizers. I contend the defence of a coaling station is to be what Alluiral Colomb wishes it to be-purcly local defence for thic protection of the stores and of the stations themselres. 'lhere are some otler points I should like to mention. There is a minimum defence, and when Admiral Colonb spealis of a large expenditure on giguntic works of defence, I rery humbly think that he must hare lasd in his mind the lbritish line-of-battle ahip, which is the only gigantic defeusire work that $J$ know of, the only one that (ail nt the present monent ro:t any rery large oums of mones. Our work docs not cost rery large sums of money, for the vers simple reason that we do not get vers Jarge sums of mones to spend upon it.

Capt uin FitzGer.ted : Where do the 16,000,000l. go agninst our 12,000,000l.?

Major WALEE : It is imposs:ble for me to answer that point witluut notice. I hare only been able to pick out a few points, ant, for rensons that will be obrious from the pusition I hold, I liave carofulls aroided figures. I aniglit hare been told that I was treuching upon things with which 1 had no busincss to interfere : therefore I must ask Captnin Fitzgerald to allow me not to quote figures. Take Singnpore. Captain Fitzgerild hus pointed out tlat Admiral Colomb assumed two much when lie assumed that a squadron, after liaring coalch, tad exliausted all the benefits that can possibly be obfaincd at Singapore. Captain Fitzgerald pointed out that there would renidin a large quantity of coal still esfe. I um trying to get nt tho relations between fixel fortifeations and a moring tect. Iou hare there a quantity of coul : jour flect coals up, ned, I presume, wuuld linve to go awas to curry unt their proper business. Fou cridently intend that the fleet is to go awas from Singenpore; but if there nre no fortificitions there a flect cunnot go awaj: the fleet mist et:n aud protect the coal. On the other hamb, if the port is protected by a few light guns, the flect will be at liberty to go away and follon its own rocation of protecting commerce ; nnd ulthough the enesny's cruizers may, and no donbt will, interrupt the suplyly of coal, still they connot dicstruy the coal alreally csisting in llint jort.

Captain Firzormad : 3ras thes not talie the conl with them?

Mujor Waleen: 'That I leare naral Oflicers to say. My point is that there will l,e oume left to protect, and you must hinie sometling to prutect it. That is the 
minimum defenco; but there must be some defence, or you will lose your stores. I am now looking at it from a naral point of riew onls; but is there nothing on the scu except Her Majesty's Fleet? Is not the primary reweon of the existcnce of IIer Majesty's Fleet the protection of the trade routes and of cummerce? Aud if the flect goes away amd leares Singapore undeferded, what will happen? If it leures it defended, then a cowencreial vesscl, chased by cruizers and himpered bj tlo encws, will run into Singapore nud obtain shelter under its guns. Will it not be better, when Her IInjesty's ships counc back to Singnpore after their cruize, to find insterd of a line of blackencd hulks along the ehore, a line of trim merchant resse!s lying at anchor safely under the guns? 1 think there is a case in which tlicesistenco of fortifications does free a tlect. 'There is unother question-about IInlta. Admiral Colomb altuits the necessity for the fortifications of Multa: he ndmits the importance of the dockyard of Sialta, and he appears to me only to object to its being any further strengthened. I so read the paper. There is a very small amount of work beiog done at Malta at a rery small cost. The fact isund I thive I may say o much nithout saging angthing wrong, or revesling any eccrets-that the opinion of erers Officer $n$ ho is officialls, or erer lans been ofticialls of late scars, resillent in Malta, is that this slight increase is not only a good thing but au absolute necessity, if the place is to be detemelexl. Then can jou for a mowent ang that this slight addition eliall not be wal te to a fortress to bring it up to equality with modern armanents simply because it now needs a large fiect lo take it? I do not thiuk it does need a Jnrge flect to do it nny dumage. There is nnother point about Inalta. It is said that no port could crer rcsist an attack from the sea. Upon that I will simpls name Cronstudt und Sebastopol. Again, Admiral Coloub asgerts no attuck is possible where therc is auy fear of iuterruption from the ses. I take the Aduiral's own instance-Tobago-where an attack was successfully made under corcr of a flect; but can you saj jou will nercr lose thic commund of the sca locally to some extent, ns you did at 'lobago? There, again,

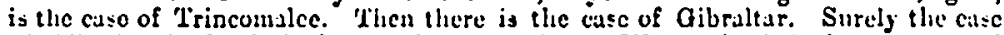
of Gibraltar is clearly in farour of fortifientione. We regaince the local command of the sea, ntid Gibraliar was relieved : we lost it again, und Gibraltar was again attacked. Now, had not Gibraltar been fortified it must hare fallen. The posses. sion of a fortress docs not follow the cournand of the eis. The French beld Jinitia for two jears after we regnined posscssion of the Blediterrancan-and Maltu is an jolarid. If Jlalta had been on the Freuch mainland how long would they lare beld it? If Mrulta had been to France what Gibraltar is to Spain the Frencli would have held it for erer. We could nerer bare regained it simply by regaining the command of tho eci. I way saly, in conclusion, thint tho question which et rikes mo us being one of common sinse sinjply amunnts to this. You sas we want tho commund of the sen. Wo all admit that the l3ritisle Ninty is our first lime of defence, and it must be made as eficient 29 possible. What docs the comviand of tho eca mean? Is it possible that unybody cun staud up here and saj that he belicres tlist a fleet can be nade so strong thint it slinll at ull tiucs, in crery sca, olf erery port, on crery trade route, be invariably superior to all possible attuck? If it be, Alluiral Colomb's case is proved; but 1 eay common sense answers "No;" and $l$ eaj tlat iny contention is proved by the fuct that now, in time of profound peace, we are in a condition in which we are adnit!cd-not by genersl opision, but bs the opinion of experts, of peoplo who know, to be behindiand-to bo eo unuch behindliand with our Flect, that it nceds a sum, rariousls estimated, from $12,000,00 \cdot l$. to $100,000,000$. to put the Flcet on un equality with what? With the Flects of any two Power:-supposing that we have two Powers combined against us? 1

Colonel Frssen, C.SI.G., R.F. : There is one point on which all sccm to be agrecd a fully us we are all agreed on the imprortance of etrengthening the Nory, namely, on the pat riotism that has avimated the lectures in bringing forward the subject. it

${ }^{1}$ Since the lecture the Fleet las been declared offeially to require an cxpenditure of $12,100,000 l$, beyond tho orlinary expenditure in the next four years, to bring it l:p to it s proper rclatire strength; and does eren this satisfy nurul Oficers? Where then is Aduiral Colomb's perfect Flect? 
this stage there is less to be eaid, becnuse naral speakers lince expressed dissent frum what, if an old friend will permit me to ear so, are the more etartling cceed. tricities to which he has giren way. I will not, therefore, touch on more than one or two proints. First, ns to the origin of the defence of naral ports. Aduiral Colomb scems to think that we adopted the practice from waut of thought and have stuck to it through obstinacs. That line of argument rould, I think, be cyually applicable to the creation of the British Sirs : we borrowed the ark from Noah; and since then we liare borrowed ironclads from the "JIerriniacs" and the "Mlinutitiomas" and other monsters !' nutl we all go on building ironclads of new types, bnowing full nell that they are destimed to be obsoletc. We do this, not to curer our past follies, but. because we do not know what on carth to do better to anticipate the future. I confess I think the siupler solution of botli these questions is that defended ports and ironclads are the out come of our necessities and. in the clerelopment of specics, they mark this "enerival of the fittest." The lecturer hits based hig arguments on nasal history. There are fex things history will not prore or disprore, nnd I slould like to tonch on onc csauple lic quotes, all the more pertinent because it is one that has happened in recent liuses und with ironclad Qeets. IIe points out that in the war of $1570-71$ an Adniral on ono side, with all the fricdom of an undcfended bage, and with an enormous naral preponderance of force, was prerented from bombarding a town on account of the presence, I lhould lare eaid absence, of a rers inferior hostile Deet, 700 uiles awas. Now, if a General on land were under eimilar circumstances, similarly deterred, we should, I think, say that Qeneral wns "unfortunate." I an quite prepared to admit that there mas hare been naral reasons for the ddwiral's inaction that a landsman cas.. not fathon. Hut if there are, then I renture to say the teaching of history in this case is this, that the best way of strengthening the liritish Narg would be so to reduce its strength as to sccure to it that preponderating infuence orcr all superior forces that, judging froin this crauple of histors, un inferior force ecems to possess: I sig to reduce its strength; because if un inferior force can always restrnin a elyerior force from taking action, then you will best ot rengthen the british $\mathrm{Na}$. so redncing it that it will alwars exercise the restraining power orer its superior enemies thint this nect of Germany is suid to hare excreised orer the Frencli. In fact, according to this esample, a small Bect of elips ut the Hebrides will protect Great Britain and Ireland. I only mention this as an cxample of the teaching of listors. I think you funcs I am not nn interpreter of listors. I aures with Jou in this instance at all erents. Rather than accept euch a conclusion it would, I think, be a race between jou ankl use and the lecturer to throw this particular Admiral to the whales and to send history to saturn, a place where I an told a depott has lately becn starled for conclusions which hare cessed to agrce ritl our own. Some people hare been trying, I will not veuture to sas to frighten the Admiml, becnuse in his case that rould be iropossible, but tlicy ecem to hare malc him "rcrs uneass in lis mind, with grucsouc pictures of rast fortifications ruund London, of a rast line of fortresses round these again, and so on to the coast, lic whole defended by rost armies of the Contincutul trpe; amd, worst of all, of a simple-minded Chanecllor of the Exchequer led into wrong pal hs when he ought to be following what, we agree with the lecturer, is the better way." Now most of us know a boges when we sec it cxecpt, apparently, the lecturer, and 1 renture to say this is a rery pronounced bogey indeed. It reminds one of certain figures one sees at fairs, that ure put up for thic cxpress purposc of bcing bnocked down again. The inrentors of this boges liare drawn on their imaginations for their facts. Those who gorern this countrs hare all the facts before then. I only wish to goodness the public rere as cognizant of these facts as the Gorernment must be. If they were, I think the intercst in the strengthening of the Nars would exced all other interests at present. No doubt the Gorernment, with erery incans of judging the

1 Hefence on land and sca lias alike undergone greut changes since 1862, but tho fortifications of Portsmouth and Plymonth are at leset as enficient for the defence of those plices from attack an are slips of the "Warrior" class to take a place in the liue of buttle. 
merits of the question, and with a weight of responsibility which we hare not, will best decido what mensurcs are to be taken on land, and what is to bo done nt sea. If I may renture to make one broad criticism on this adnirablo lecture, in Fhich, if there is a good deal of quartz, there is not a little gold, it, is this : jou do not improre the case of the self-erident and the unanswerable by piling up arguments which, on the authority of naral speakers, appear to be not only answerable but in their opinion untenable. And to the bogey-mongers I should like to sar, you do not heighten the effect of a pieture by throwing dust in tho eses of those whom sou wish to admire it, and to be influenced by it. I next come to tho remarks made by a most genial speaker and already noticed by others. Captain Fitzgerald has ecttlecl a little side issue, namels, that connected with land defence. Ho has pronounced authoritirely, ex cathedrd, that we are " not in it." Well, it would bo uncourtcous to say that there is a differenco belween aszertion and argument, but let us sec what he asserts. We do not want to eet up a bogey, but to stute as fairly as ire know how tho contention that he and others liare put forward as unanswerable. It is, I think, contended, first, that inrasion is absolutely impossible uniess and until our porrer at sea is completels and once for all destrojed past all recall; sccond, that no ono will take the trouble to inrade us because they cun starre us out. We all agree that when the Nary is put in the supreme position in which we desire to see it, then we mas hopo the seas will bo as safo as in peace-time, and the ides of inrasion will be absent from our minds; that in the meantime if our Nary be gone completely and past recall our Empire will hare gone with. it; in whicl, case there will be little left to lire for, not to say to fight for. And it rould only remain for the "unfittest" half of our population to set to work and die off at once. I am not a panic-monger, but, while I think the contingency of inrasion to be remote, it does seem conceirable in a state of things considerably remored from such a dreadful cataclyam as the eatire annibilation of the British Nary.

Captain Fitzaradid : No.

Colonel Frsser : That is a rery fair difference of opinion. We hare becn told that in these questions the appeal is to history : to history let us go. At the be. ginning of this century we were supposed to be supremo against the flects of tho world. Wo had fewer rirals to oppose us; less territors and fewer seas to hold than now; no coal to think about, and relutircly to our strength a larger number of ships to be "ererswhere." At that time naral nffuirs entered much more into tho life of the people in this country then thes do at present. The population of these islands was about half what it is now, and get the people of Lngland thought it necessary to maintain a total of something libe a million of gghtung wen. If in the opinion of our forefathers at that time invasion mas possible, are we rise in coming nbsolutely to the conclusion that it is entircly impossiblo now ds regards the militars possibility of the operation, the greatest master of nar the morld has crer seen thought it Jeasible; and the Gencral who defeated him has recorded his agreeuneut in that opinion. What were the conditions in 1805? Armies mere slorly organized, more slowly concentrated by road. The northern coast of France was not then prorided as now with great artiticial harbours. The floats that it was intended to ust were little better than those in which Cxsar and the Tenth Legion successfulls macle the passage : and the dilliculties owing to their being depandent upon wind or oars were very considerable. Wliat is the etate of the case now? The north of France is prorided with rast and conmodious harbours, the last of which was opened, I think, only two or tluree days ano, and in those harbours there are always great numbers of atcamers that can, as the lecturer has pointed out, more with a certainty that was unknown before steam, and can cross in a few hours, while we nll know the rapidity of modern mobilization. Lastly, the lecturer has giren it as his opinion that Napoleon's failure wns due to Villencure's want of nerre. It may be so, and that if the grent leader could hare inspired that broken reed, as he inspired his soldiers, the attempt might hare been made; but there is one lesson thut we cannot, I think, draw from history : it is that what the incupable hare failed to perform in the past the capable will alike fail to perform in the future. If ne disband, as Captain Fitzgerald suggests, I think we incresse at once the temptations to inrasion, and-inrasion itself will be possible with largels reduced numbers, whilo re sould be incapsblo of thoso offensire returng by which our 


\section{Enpire was won, and by which alone wo can close with an enems we cannot} starre.

Captain Fitzaerald : I nerer suggested disbanding.

Colonel Fraser : In the erent of certain contingencies, I would ask how do we stand ot this moment? Are sou prepared, or nre sou not, at onco to safeguard 13 ritain, to sccure the Greater Britain, and to hold our trade roads erergwhere at eea? If you are, why do you, as we think rightly, ask for an augmentation of the Nary? If you are not, what are you going to do for some years to come? Are you going to palisade England rith a floating boom of ships and leare our cominerce to our enemies? In such case, while you save us from them. We stand to lose the Empire by which re lire. I do not presume to sisy hor you will do tho best you can to safeguard us evergwhere; but you will doubtless try. Mleantine this is not, I think, the moment for putting aside the terrestrial string to our bow; nor until we get a bigger basket should we put all our eggs into one. While we put our faith in the British Nary I think we ought to keep our powder dry on shore. Finally, is it so certain that nobody will talic the trouble to inrade us because they can starse us out? There is a wide difference between the starration thal would follow your annihilation, and the ups and downs of a protracted war, in which our coinmerce may often be internepted us it has leen before. This country, where economic laws now impede cultiration, can, at need, feed a larger population than in 1505. Unless all our ports are effectirels blockaded neutral ships can conte in. While the success of blockade rumning, even if for a moment we come to that, points to the influx of much food at the worst. The starration boges has, I think, beenexaggerated. In the autuun we hare six montbs' supply in this country to carrs us through the winter. It las been suggested we should bare breud, but our people could not buy it. In sucle cuse, not to take higher ground, it would be chenper for us to put the loor Lam anachiners into inotion rather than to pay fire times fire milliards and hand orer our Empire, including the British Niry. If Niclson hins a successor he will Icad you sonetimes to Copenhagen-to Aboukir-to Trafulgar. Doubtless sou will hare ships in narrow scus as well; and we would expect you to beat your encins 23 of old; but none of us, not eren the most inesperienecd, can predict with ccrtainty the result of erers nural fight; because none of us know which ehips and what methods will prerail. We hare to think of the stukes that other people will be playing at. Each side will strike with its strongest arm. We cannot crush, s:as France, on land, on account of her immense armics, nor can we starre her out. On the other hand, the capture of London would terminate an otherwise interminable war, would transfer our limpire to our cnewics ; and last, but not least, among the moral factors that control the acts of men, such a dramatic success unight be attempted as the onls means of perpetuating the dymasty of a dictator.

Admiral the Kight Hon. Sir J. C. J. HAs, Bart., C.IB.: I have learned eo rery much from ung friend Admiral Colomb on former occasions that perhaps he will forgive me if I cannot on this occasion thank him so much for his paper, ut least for the intormation it contains, as I would have expected if I had not licard the paper. The adrantage of the paper has been the discussion which it has elicited, and, I beliere, that was the object he had in vien. MIy gallant friend began bis paper with I inistorical fullacy, because he speaks as if an inrasion was something which could not possibly be anticipated. I would only say that the sliades of Williain the Conqueror, ur Heury Tudor, or Dutch Willian would contrudict that assertion. I beliere that this country las frequently been successfully invaded, and that it uight be inraded agrin. I am one of those who think that it is open to invasion and that such a thing is possible-I hope it is not probable. I mas sas that when I seconded Sir Frederick Sinith's motion in the House of Commons againt the expenditure of $14,000,000 l$. on fortifications, which I thiuk was a very considerable sum, whaterer $M$ :ijor Walker may say, I dicl so, not on the ground that I did not think it desirable that Portsmouth or Pymouth should be fertified, although at that tiune I did propliesy that the forts would not probably be completed or armed for a rers long time, und I beliere I was tolcrably accurate in that supnosition, but it was because I thought that Filey or the Black Kirer in Fssex, or l'evensey Bay, could not be de. fended by the forts at lortsmouth, and that a great fleet is necessars for the prutcetion of our shoris and for the prerention of invasion. I understand Admiral 
Colomb's paper to mean this. If the anount of unoney to be spent is limited, first of all complete sour flect. I go with him as far ns that. But to say that fortifea. tions are useless is against that ancient history which mr gallant friend referred to, but as to which he, in the meaning in which he uses it, is in mr opinion wrong. When Lord Nelson or Lord St. . Vincent blockaded Cadiz, why did they not destrog the Franco-Spanish flect? Becauso Cadiz was fortified. Why did Iord Hoorl take possession of Toulon-though an ignorint Secretary for War and First Iord of the Admiralty who nere cirilians did not support him when he lrad posicssion of it-mliy did he make that the baso of his operations for a consillerable time? Hecause he had got at the French leet, and because the fortifications of 'Youlon were not at that time manned to oppose lim. $\Delta$ s soon as thes were mained to oppose him he was turned out of Toulon and lost his baso of operations. I ngrco witli the last speaker that what we want is a strong Nars, and I clisagree with him in thinking that you cannot get a sufliciently etrong Navy for the purpose. I thiuk he stated that at the heginning of the century wo had conceired it necessary to havo a sufficient fleet. We had, on the arerage, 1.16 sail of the line always at sea, or reacly for sea, in nddition to a number of others which were not arailable. And when wo were not superior to the whole of Furope we took pussession of the Dianisla fleet in 1807 , nnd then made ourselres superior to the whole of Europe, and n vers rood thing too, I think, and I am glad it was clnne. It made us superior for the rest of the war, and if we had done it earlier in the war, if we had kept Toulon and had scized all the flects that might have been opposed to us, as we dirl the Russinn flect in the Tagus and the Ianish flect, we should hare had the command of the sia as me had from 1807 until about 18:10. I an not entirely hopeless that the count ry minht rioe to a great zpirit of indigation, and may suy that for erery battle-ship which is opposed to us we shall hare one bere-that we shall hare ship for ship against crersthing that could possibly be brought ngainst us. The gallant Offices who preceded me secins to think that their days nre numbered; in the meantime other people hare got them, and $\pi \mathrm{c}$ must hare them also whaterer they cost. I agree that until our thet is made sufficicnt for that purpose we liad better not epend money largely upon new fortifications. Those that we have ought to be arancd. Those coaling otations which hare been recommended to be fortified shoull be fortified against raiders and cruizers, and the sooner the better. I trust that when $\mathrm{my}$ honourable and gallant friend the lestures stands up to reply he will put on a penitential sheet, or rill, at least, tell tho necting that he hai been humbugging them.

General Sir J. Isixtory d. Sry yoxs, G.C.R., G.C.M.G.: The paper which has been read to the meeting by Admiral Colomb is one of very great interest, but $I$ think he has gone a step bejond what his conscience rould dictate to him as tho proper thing. Ie has done it, I hare no doubt with the best of intentions, to clicit discussion. But the question 23 it stends at present is one which is rather of an acadernical than of a practical claracter. Ary reason for saying so is this. If the flects of Great Britain are suficient to maintain absolute suprenacy on tho seas in all parts of the world, so that itwould be impossible for hostile ships to come near us and annoy our ports, and lers contributions from our towns, und destros our couling statione aud commere, then I say we want rers little nore. The Army would in that casc hare to defend our land frontiers in India, Africa, and America, depend. ing upon the Nary for the snfety of their communications, and would not be necessary for the defence of these islands. But I should like to aok, Is the flect iu tbat con. dition? (No.) You all say vo; and I beliere myself it is in a very unsatisfactory cordition for tho perforrance of that great function. Having lired in a naral port for some jears, I harc obscrred that the Commanders of ships of war, eren in peace-time, when thes arc not compelled to keep the sea in all sorts of wenther, and hare not snenems to mect, are rery ylad on coming into port to find a dock in which their ships can be refitted and repaired before going to sea again. The wear and tear of ships of the present day is vers great. That is the experience that $I$ hare gained from liring in a naral port for four gears; ships of the present day requiro constant attention and of sucli a nature that the repairs cannot be done by the ships" companies themselres, but must lare the machinery for effecting them. That being the case, cosling atations are not only of use for coaling purposes but they are re- 
fitting stations, of the greatest importance to the Nary. Setting aside the question of coal, if a lostile cruizer could get into a port in which you lave the incins of repairing ships, and could destroy those meuns, it would seriously affect the efficiency of the Nury. For instance, let us consider the Mediterranean. A ship that wants repairs in the Mediterranean has only one port it ean go to for them, namely, Malta. If Malta clocs not exist as a repairing port, where is the nearest port? It is in Great Hritain, in the United Kingdom. Can sou nfford to be sending your ships howe all thist distance to get those repairs which are necessary? If you are corapelled to send your shiphs theso long distances to be repaired, jou will require many more ships to beep up a blockade or to obserre an encmy's ports. Now, with regard to the suflcieney of the Nary for the purposes which I have indicated, and for which it ought to le inaintained, we hitre the strongest eridence as to what is necessary. A Report has been published within the last few days, sigued by Admirals Sir Wiliam Dowell, Sir Veses I Iamilton, and Sir Frederick Richards. What is it that these dilmimls, not discussing in this theatre, but haring a lue sense of responsibility, haring studied the subject closely, nnil secn a grest deul of evidence-rizat is it that thej report? And remember that the I3lue-books contain onls ext racts from their Report; there are probably mans things in the Report itself which cannot be publiahed to the world. It is very diffieult to discuss these questions fully in public, because there is a rast deal of information which cannot be placed before the world. I say this adrisedly, haring been a member of the Commission of which I.ord Carnarron was President. We were for a long tine occupied in tiking eridence, some of which was given to us under a strict bond of eccrey, which is possibly the reason why that Report hins not been published.

Sir J. C. R. Conosin: I quoted from the published Report which appears in the Appendix of the Colonial Council.

Sir Listorx Sisuoxs : I3ut I beliere the whole of the Report has not been pub. lished. I was not aware until I,ord Caruarron alluded to the passage in that Report respecting the Nurs that anj part of it had been published; certainly the cridence on which it was bascd has not becn published, and l suspect that similarly a great deal that was before these Admirals could not properly be published. It would be as unwise to publish the facts upon which the lefence of this great Empire depends as it would be for the Germans to publish all the echemes of at tack and defence across their fronticr upon which their great system of defence has bcen determined. I will go back to the recommendations of the Admirals. Thes sas: "It is not necessary" to point out the incalculable mischief that so enterprising an encmy might inflict in cren thut sliort time (that is about thirts hours), and low imperatire it is to coin. plete the uilifary defence of our great commercial centres without further delas." - Tuwards the end of their Report thes say: "It would be far moro in consonnese with the requirements of the nation by the prorision of an umple fleet to remler inrasion an impossibility, than to enter into costly arrangennents to meet the eneny on ourshores, but under the conditions in which it would be possible for a great Power to successfully iurade England nothing would arail her, us the command of the sca being lost, it rould not require the landing of a single unan upon our shores to bring her to an irnominious capitulation, for bs her Nary sle must stand or fall." Now, I belicre mrself that the 2 ars is the Grst and most importunt line of defence. We cando nothing without it; ereryone in this country must be of that opinion. But I do not quite subseribe to the opinion that because the Navy might hare been worsted for a time in any particular eea the country is to bo inraded or reduced to subjection by starration. I beliere that our Nary will be distributed in rarious parts of the world. It will not be all in ooe great fleet, and one great battle will not decile which is to be the prerailing Poner at sea. Supposing a flect blocknding lerest or Clierbourg, or anj otlier port, Tere worsted, and it is quite possible tliat it might be rorsted, becausc it would be figliting under unfurourable conditions in comparison with the enems, whose ships being in port would be frce from wear and tear and not liablo to loss, whereas the blockading fleet would bo subject to the raging of the elcments and to accidents, and would be kept continually at hurd irork with a larige amount of wear and tear going on-supposing under those circumst nuces that this fleet were worsted, it durs not follow that all the of ler dects of Great IBritain in other seis should be worsted likewiec; and it does not follow if there are naral 
norts sccured by fortifications, for the time that thosc flects could not find their why into them and that thes could not be brought together and reinfored; so that there is no rcason wby we should not resume the supremac5, that is to sny, pro. rided that we hare a sufficient number of ships. But, in the meantime, while this assembling of tlic flcet was going on we certuinly might be exposed for a time to great danger on the shores of England. This danger may be of rarious sorts. If it were intended to subjugrate the country, a force of from 150,000 to 200,000 men, or perliaps more, might be required; but what should be eaid of an iurasion with 10,000 men, necompanied by such neasures as those which would hare accompanied the inrasion had it taken place in the time of the First Fupolcon? I looked up, the other day, what Napolcon himself staled with refercuec to this question. Ue sail: "The cauaille of all nations are nearly alike, I would hare made such promises as would hure had a great cffect-the proclamation that we came as friends to reliere the English from an obnoxious and despotic aristocracs, together with the proclaiming of a republic; the abolition of the monarchicul form of gorernment and tho nubility; the declaration of the forfeiture of the land of such of the latter as should rexist, and its dirision amongst the partizans of the rerolution; and a general cquilization of the properts, rould hare gainch the support of the canaille, and of all the idle, prodigate, and disaffected in the Kingdom." If 10,000 men mere discmbarked on the coast of England, their numbers uight, be magnified tenfold. I do not incan to say they would bring about a rerolution, but if retolutionary clocuments such as Tapolcon desigued were scattered broadcast throughout the country, and all sorts of promises made, I think some of the gentlemen who frequent. Trafalgar Square woukl only be ton delighted to throw in their lot with the in rader. The whole of these questions depend on the possibility of the Finy doing the work which the gallant Adnimls dessribe as their duty. 'The Adniluls in their. Report said : "That the Channel Flect (so called) should, supposing the eneing to be a great miritime lower, be of sufficient force to blockade the flect 3 of such lowers in their ports or to bring them to immediate action should thes put to sea." That is the first requisite, but what does it imply? It is just is necessary, I presume, to blockade (spcaking subject to correction in the presence of so mans Admirals) not only the flects in the hoine ports of the Powers with which we may be at war, but their flects nlso that inny be in the China Seas, in the Jeditermenu, or on the cuist of Africa, or nnywhere else. This inrolres a ress large fores, and then therc is another thing : history tells us the enemy's feets hase not always remained in their oxn ports, and it is possible for a large lect to be detached before the com. mencement of wax to a neutril port, in which caso thes could not be blockaded, lecause bj doing so you would bring upon you the hostility of the Power to whmm the port belones. (No.) If you aitempt to blockade a ship in a neutral port you are lisble to bring upon you the liostility of the nentral Power. (No.) Whether that be so or not this Cliannel Flect will have to be of immense dimensious; the Admirals state in the proportions of fire to three of battle-ships alone to blockade the enems's Acets, which I tuke to be the object whererer thes mas be. 'Therefore it would be a fect, the duties of which will extend bey ond the Channel, cren to the Chinese Seas. That is the first batch of ressels required, namely, the so-called Channel Fleet. The ddmirals then go on to say: "There should always be an effectire Reserre Squadron, absolutely confined to home waters, sufficient to hold the Channel and protect the coists and comnerce of the United Kingdom." That is a rather largo order; it eridently points to the possibility of the blockading squadrons not haring bren suecessful, and tiat hostile dects inisy be on jour coust, otherwise this Reserve Sylunlron would bo of no more value than it is contended the fortificutions for the difence of harbours are, because, in fact, if sour blockase be perfect, the cnemy can urer come near the coast to bring this Reserre Squidron into action. Then comes a third lot: "in addition to the district const defence ships which would be neceseary for actire local defence on the const of Great Britain, Ircland, and the Channel Islands." "The abore constit ute three requirements. 'The fourtl is: "that there should then remain arailable n sufficiency of battle-ships and swift cruizers to reinforne our squatrons abroud to the neeessitry point of superiority with referenco to the requirenients of cach station, for the forination of detached squadrons and conross for commerce and troops orer and abore the number required for home und. 
Mediterranean ecrice." That again is a pretty large order. And, fifthly, "an amplo reserve to meet the wasto of war." . Now I do not mean to say ans one of these fire requirements is not necesoary, but this I do eay, that. I beliere, subject to correction, that your leet at the present moment scarcely fulfile the first of these conditious, and before you get these fire requirements complete, jears must pass and a rast expenditure must be incurred. Tlie Nayy lias been let down to that low point that it would require a long time to bring it up to the strength considered necessary by these three Admirals, men of great experience, who baring before them the reports and opinions of other Admirals hare, under the weight of responsibility cast upon them, stated their opinions to the country; it is of importanco that this slould be borne in mind; at the sane tiuc, and ecrtainly for the jears that must clapse before the flect can be brought up to this strength, I cannot subscribe to the theors that forlified coaling stations and defences for large mercantile ports aro not necessary. The lecturer has made allusion to Gibraltar. What are the facts? It is quite true that the Army alone cunnot hold it for any great length of time without support. We, the Nary and Army, must work together. The communication with Gibrultar can only bo secured and its rericlunlling carried out by the $\mathrm{N}_{2 r y}$, but in the absence of the Nirs the Army can liold it as loug as the prorisinns for its garrison last. What was the use of Gibraltar on one memorable occasion? After the Battle of Trafulgar Admiral Collingwool took his Acet in there: he was rery glad to find a port nesr at hand where he could refit and repair. The converse happened with Admiral Dumanoir, who nude his escape after the battle with four or fire line. of-battle-ships; and was met by Sir Robert Strahan on his was to his port 600 or 700 niles distant. If he had had a port under his lee, or within 200 miles, he rould hare got into it in safety and so preacred his ships. What happened as regards Malta? It entered into Napoleon's design 3 to get possession of it. Ife went there, and in the course of two or three dajs the garrison got frightened, or rather there wits trenchery in it., and they surrendered ; but if there had been a British garrison there no doubt Mfalta would not haro surrendered, and it would hare been secured to Felson during his operations against the French Adiniral. These are points which hare to be borne in mind. Then, again, reference hias becn repealedls made to Singapore. I think the necessity for the defence of Singapore by fortification is evident, it being rery distant, in a position in which trade concentrates, where there is necessarily for commerce a rery large nccumulation of cosl. I bnow at one time there were $1 \cdot 10,000$ tons of coal collected there merely for commercial purposes; well, a large depot like that is of great usc to the Nary ns well as to the commercial marine. If there were some moderate defence there to becp off such a squadron as is likely to attack it, Her Majesty's ships having coaled thereand gone to mect their enemy, might feel assured that on their return they would find not only coul but machinery to repair their engines and assist them in putting their ships into a proper statc of efliciency. I think thesc are grare considerations, and I may sas this with respect to I.ord Carnarron's Cominission, that it endearoured, under the deep scnsc of responsibility which rested upon them, to ninimize the defence of coaling and refitting stations to the utmost. We had to consider, in the case of erery port which was proposed to be deferided, the natire of the attack to which it would be exposed, and the means arnilnble in the place for the assistance of the troops. That was done most amply in the case of all those ports, and $I$ beliere the defence of each ras minimized to the utmost. It is not a question of millions of mones, and direrting these large sums, as ha becn stuted, from the Narg. The amounts proposed to be expended were not so rery large, and I beliere that the expenditure that was reconmended is absolutely necessary, not only for the ships of the Narg, but still more if possible for the commercial marine. I do not bnow that I hare much more to say on this subject. I think perlıape you may consider I am riding my hobby-horse to death in saying it, but it uppears to ane that the rhole of this discussion points to one thing: we in the Army and you in the $N_{a r y}$ are two separate departmente working for one purpose, that purpose bcing the defence of the fimpire. We are all decply ivterested in it. I should be rery sorry to 885 one word, or see anything done by military men which would derogate from the efficiency of the liary, or retard its being made much stronger than it is. But my experience in years past has been that there is a pulling and hauling on the part of the two Serrices to get 
as much as thes can out of the Claneellor of the Erchequer. We sce the defects of our Scrvice, naral men see the defeets of theirs, and we cach try to get as much as we can, and it is our duts to do so, to make our respectire Services 29 eflicient as possible; but I do not think that there is that combination of the two Serrices for tho one great object that there ought to be, and I beliere the true method by which alone the measures that should be taken for the defenec of the Finpire as a whole can be properly settled is that there should be a Mlinister for Defenee, for War if sou like to call him so, and that the two Departments shall be subordinated to him ; ono Cabinet Jinister and troo others, not necessarily Cabinet Jinisters, subordinate to lim, each respousible to the country for the efliciency of their respectiro Serrices. I hare been attacked as to my idcas being Utopian, but I am happy to ece that a good unany prorincial papers have taken up my views. My idea is this, that t!e question ought not to bo a political question; and that there should be a few good men, whether you call then Commissioners or whaterer you majeboose to call them, under a Cabinet IIinister, who will consider such questions and work them out as a whole. If Imperial defenco had been properly worked out as a whole, this disenzsion would not have taken place, because the question raised by the lecturer rould lase been under the senso of responsibility aitaching to encl indiridu il wlo had assisted in working it out. 'Then I go a step further, and sny that the Jlinister umler whom such a project had been elaborated ought in some way to assist in sceing that his project is carricd properls into elfect. A question was asked bs Sir Jolin Adre in a letter to the "Times," whether it was reasonable to plize an es-Mrinister as an ussistant to a Jlinister in oflice. I can only say from ms lieart that I beliere it is unreasonable to suppose that the public men of Eingland lare not sufficient protriotism in then to work upon a non-political question, inrolring such vital interests to the Empire, in perfect harmons. All that I can say is, haring serred on Iord Carmarron's Coumission where there were men of diverenent politics representing different political parties, that we worked in perfect harmony and brought our Report to an unanimous conclusion.

Qonernl Siterv, C.B.: As I am Vice.Chairman of the Brighton Branch of the Naral Yoluntecr Defence Associntion, and haring taken n considerablo interest in this subject, I am extremely glad to hare hearl the rers able lecture of my gallant friend, in most of which I fully concur, though I feel that he somerhat rode his lobby to death. The Arusy and the Navs, since the disy of our being so closely ussociated in the Crimean War and up to the present time, lare become more than sisters. We are twin sisters, and most nffectionate sisters. Now, as regards what the gallant ddmiral has adranced, I also am perfectly satisfied that the defeusiro wars of this country will, ard indeed must, be fought on sea and not on land. I aw perfectly satisficl, howerer, that the Army and the Nary must work hand-inhand if England is to remsin a first-class Power. The fact is, I am satisfied that this .country will nerer be inraded. It ceases yearly more and more to be eclfsupporting, and thus partial inrestment scens more and moro its chief danger. Now I do not for a moment deny that it is perfectly possible to inrade Fingland. I know of 50 miles on our south coast where I could select three or four places where with perfect certainty you might throw 200,000 men on our shores, either as one army or by arms corps, at spots sufficiently contiguous to be able to gire immediate support to cacl other as one arm5, corered of course by an inshore squadron, or squalrons carrying hears and long-range guns, and prorided the reather was woderately fair. But the conditions necessary to such inrasion would render inrasion an absurdity. Why should an cremy inrado England? The conditions necissary would be similar to those that occurred in regard to our inrasion of the Crimea, viz., that our cnemg must hare us complete a command of the British Cliannel as Fngland and Frunce had of the Black Ses when ther landed at Old Fort. And what would that imply? It would impls that our Nary was utterly shaltered, that our commerce had been destrojed, that our food routes were cut. It being so, whs should any countrs inrade us? In these democratic days, with sewi-starration you would hare a Commune in London and rerolution throughout the country. Your arms of defenco would be threatened by the enemy in its front and rebellion in its rear. Our countrs bankrupt, our population starring, we should be at the merce of our focs. Why, then, should they wiste men and money on

vol. XxxIII. 
inrasion? If we are starred we must go down upon our knces, and no doubt our enems would be able to denand any terms that lie thought proper, inclucling the giring up of the remainder of our flect and an cnormous indemnity, with Dores and the Thames and Jedras as a material guarantec, anil if the Channel Tunnel be completed, then witli a perfect communication with the Continent. I3ut as regards the gallant Admiral's ablo lecture, I must make this strong obserration in opposition to what he has saicl. The Narr must be thorougly and cfliciently conl-fed from shore-protected depôts in crery part of the world, giring our ships thorough fredom of action; our military ports and large commercial ports must hare permanent and good defence. With rerard to ingress and egress from those ports, I admit that that must be entircls dependent upon the fary. We slould lave batte-ships equal to any conbination that is libely erer to occur, and cruizers, not according to the number of cruizcrs that other nations lare, but cruizcrs in proportion to the rast quantity of merchant shipling, on the defence of which our rery cxistence ns a mation depends. Then, gentlemen, though a soldier, I say leare the Army for the present as it is, and use your cnergs to mabe our Nary as strong and efficient as possible.

Iicutenant-General Sir Joirx Srokrs : It is a great presumption on my part to rise to address this audience, but there is one point which I do not think has been quite brought out. I think wo are all agreed that the Firs ought to be our first line, and as strong ns it can be made, and that in order to bring it up to that point it will require a grent many Tears' work. Adniral Colomb in his paper deprecentes spending money on fortifications which wight be better cmplosel in ineressing the strength of your Nary. Hut those fortifications which are asked for, for the defence of our coaling etations and our conmercial ports, would not inrolre a rery great expenditure, cren if sprend orer a comparatirely short time. Mrans jears must clapsc, as I eas, before our Nary can be placed in the state which it should occups in order to maintain the command of the sci, and nntil that object be attained you want your fortifications in order to defend your depots on shorc, and, therefore, us nn interim measure, I say let us lane the fortifications. In this cliecussion, conparing present times with past times, I think it mas hare been said before, and better perhaps than I can say it, that in former wars our flects and cruizers were self-contained. They could go to sea and remain months at sea, and could hold their own until thes were absolutely driren back b5 being dismasted by storms or during action. In these days you cannot keep the sea; yon must go back for coal, and you must go back to refit. I think that point, combined with the of her, shoms that we ought to hare protected stations, in which our ships can fincl what they want.

Sir Listors Sissioss: I omitted one point of rers great inportance, and, thercfore, with your permission, will std a few words to wilat I hare saitl. In 1803 , at the conclusion of the Peace of Imicus, our total naral and militars expenditure was $23,590,75 \%$. In 1814 , as the result of tlye war, our maral and military expenditure got np to $71,656,707 l$, and we paill loains or subsidies to foreign States to the extent of $8,412,5781$, naling a tot al of 80 millions for the war expenditure for the Jear, being the espense $\pi \mathrm{c}$ had to submit to in order to maintain our position. Last jcar our total military and naral expenditure was 30,785,6S7l., bcing an increase of only 30 per cent. upon whint it was in 1503, while the population had increased from about 16 millions to 37 unillions, or 131 per cent. The charge per head of the population for warlike expenditure in 1603 was 29s. 53 d., as compared with 16. $7 \frac{1}{2} d$. in $1 S S S$, or 14 per cent. less, so that we are very much less taxed now for military and warlike purposcs than we were in the early part of the centurs. The imports and exports in 1803 were 623 millions, and in 1593 the imports and csports aunounted probably to not Iess than 850 millions, carricd in ships, the value of which was close upon 150 millions, representing, therefore, 1,000 millions as the ralue of British proparty tratersing the seat annually at the present time, of which an arerage of about 150 millions is alloat erery day in the ycar, being the raluc of Britislı property upon which an enemy would have to cowvence operations. These amounts do not include coast in: trade. If a peniy on the pound were leried on the 1,000 millions of British property traversing the sca annually, it rould amount to 4 millions of pounds. Sispence on thic pound would go a long way to gire the country all that is requircd, or a penny on the pound for sir gears; and it 
is worthy of cousideration whether, as long as our policy is of a peaceful nature, any Power would seck a quarrel with us if we are true to ourselst: and aro so prepared during peace as to gire us under l'rosidence a reasounble certuints of succuss. The fact should be well pondered by erery Fuglishman that the warlike expenditure in 151.4 was about $4 l$. pcr head, and that by raising it to $1 l$. a head for a few rears cluring peace it is not improbable that wo night escape war altogether and continue in pesce, without the prospect of haring an orerwhelwing war expenditure forecl upon us.

General Sir R. IIUar: : At this stage of the discussion there is rers little left for any of us to eaj that has not been said already, either in farour of or in opposition to the lecturer's opinions, but I think, at the same time, for one or two ninutes we are justificd in getting un to express our concurrence or disinrecment with the riciss that the lecturer las so ably laid before us. If I had spoken carlier I lad many rery brilliant idcas which I should hare liad before the meeting, but so many other Oflecrs lare anticipated me that I should not be justified in taling up your time in repcating chose ide:s. I would merels ren:ark that almost the first point of Admiral Colomb's lecture is the dispersal of tles Army all orer the world, and he goes on to Eay, "I will endcarour to show chusc against this." $A$ long as our Eiwpiro is constituted as it is at present, and I hope it ulwajs will be, with large detached forcign posscssions and Colonics, it is impossible that wo can maintain the Fimpire unless our A rmy is largely dispersed all over the world, and I myself cannot conceire a Nary so strong or so ubiquitous as to cnable us to dispense with soure defences for our garrisong and for the inhabitants of those pluces that we oceupy on the sea const at a distance from Euglaud. On tlat arcount I rould sas that, granted of course the first broad contention that we unust hare command of the sea, I think that the Fary nill be supported and assisted in mointaining that coumand by the local defence of the positions which we must occups all orer the world. The lecturer, in what has been to me a most interesting aud most importaut lecture, sars, towards the end of it, that.tlec moring uars must be either in comand of the sea or fighting for it. When the moring nary is cntircly in conmand of the sea, our land fortifications and defences are of relatively minor ralue to what they will be when the Nary is fighting for it, but when our Nary is fighting for the comnand of the sea, I mintain that our land defences will te of rers great importance. I simply stood up, Sir, to occupy a few minutes in sarivg that I concur cutircly mith the lect urer where he eags that we must have the command of the sca, but I do not agree in many points, which I hare not time to allude to, in the manner in which he considers our naval supremacy should be maintained.

Admiral Sir Elsasjtes Odrassies, F.R.S.: 'lle obsortation I wish to make is this, that, assuming I had command of tho Clannel Filcet in mar-time, uctling would make me fecl more happs than to know that the approacles to our naval ports and arsenals were defended impregnably, so that I could have free action to operate against the cnemy in all parts of the Cliannel. With regard to the listory quoled by the lecturer, $\overline{\mathrm{I}}$ differ with him rery much, because I think, so far us history gocs, it shows that flects lare soldom succeded in attacking fortreses. With regard to the adrantage of fortifications, I would quote Malta, for instance. Defended as it was in former days, no elip could enter Yaletta barbour exposed to the raking fire of Fort St. Angelo and the crosi-fire from other batteries without being sunk; therefore, this irrportant island succumbed onls after blockading. Iuch stress is laid on the relicf of Gibraltar by the flect of Lord Howe during the celebrated sienc by the combined forces of France and $S_{p}$ ain, but prerious to the appenrance of this llect, the garrison of Gibraltar had nobly repulsed the formidable attack of our cremies on the Rock by land and sea. 'This impregnable fortress has proved a torrer of strength to us ns a naral depôt and it baso of protection to our comucrec with the JIcditerrancinh and Mlorocco. I, thercfore, think that our ports should be sufficiently fortifed. I wish to point out that Aldmiral Colomb lias made one orersight with regard to the operations of the French Fleet during the Francu-German WFr. The reason why the French Fleet remained inactire was owing to the scanen being sent to Haris, where thes were cruplosed in manning the detached forts when Piris mas inrestel by the Germin Aruys. I wercly point that out and will sag no more at present, unless we should have to go orer the ground 
again. I think we nre extremely obliged to Sir Lintorn Simmons for bringing forward that Report on the recent naval mancurres so conspicuousls before this meeting, and I think crery naral Officer must endorse tho opinion expressed by that Conmittce. I was very glad to hear Sir John Colomb point out the importance of the Island of Jrauritius. I know it $\pi \mathrm{ell}$, it is the Gibraltar of the Indian Ocean. I rould emplasize as strongly as $\mathrm{Admiral}$ Colomb the importance of maintaining our supremacy at sca. I say, let us lare tro strings to our bow, let us hare the forts as well as a formidable Narr, and when the cmergency arises I hope that tho Army and Nary will hare "a puil, a strong pull, and a pull all together."

Licutenant-Cclonel Festuenstoxuman, R.F.: Captain Penrose Fitzgerald challenged the dring to answer this question. Io soid the "limes" had re. marked that if the Nary is as it ought to be, no more is required. IVell, Sir, I rould just alludo to what occurred at Bereharen. There we had onc Admiral blockading another ddmiral, and we must suppose the first ddmiral was in com. mand of the sea. What happened ? The Adwirnl blockaded broke out. Whe place I was at was about thirty sis lours' stcaming from Bereharen. and as soon as we heard he had broken out we calculated lo wight be with us at fire o'clock on a certain morning. He arrived at seren o'clock, and if he had been a fast going mail steaner crossing the Atlantic he could not hare performed a more rapid or more perfect royage. These ships, Sir, thut broke the blockade touched at crery commercial port in the bingdon-Lirerpool, Aberdecn, Leith, the Tyne, the Tees, and I do not know where clse thes did not go, and there was not anybody able to stop them. I mentioned that to a distinguislied Offecr tho other dny, and what did he say to me? IIe said, " We do not inteud to defend the commercial ports." There is another cat has jumped out of the bag. The Nary mas win a -rictors off the Downs, but in the meantime erers port in the kingdom is to be smashed to pieces. Is this meeting to approre of that idea, and would the country like such a state of things?

Captain Fitzarusd : Jrag I be allowed to sepcat a short quotation I wado at the last mecting, as there secms to be some misuderstanding about it: "If the Nary is made thoroughly competent for its mork no other defenco for theso islands, or for the Empire at large, will ever be called into play: if the Nary fails us no other defence will arail to arert crushing disaster."

Gencral II $\triangle$ RDIso SteiraRD : It is now so lato that I will not detain the meet. ing more than two minutes. I wish to speak about commercial harbours. But, before eaying angthing on that subject, I must say that I admire the way in which Admiral Colomb liss attacked us Fnginecrs. Ife hiss, I beliere, clone it with an object, and I think he has gained that object entirely: although he has not prored his case. I think, howerer, that he cares but little about that. During his lecture, about the end, I obserred that he made one important admision. For, after decrying fortifications and sajing they rere not necessary, he admitted that the coaling stations ought to be sceured bj fised deferices from capture by a conp de main. That, is, howerer, all that wo Jingineers waat to do. He then went on to speak of commercial harbours and to sas that they need not be defended by fised defences. (Admirnl Colomb licre dissented by gesture.) The Admiral lias unquestionably decried the use of fortificationa for the $\mathrm{grcatcr}$ ports, and I a $\mathrm{m}$ sure that lie altogether yielded their usc for the smaller ports. At Icist $I$ understood him so. But, whaterer mas be the drift of this lerture, I want to point out that Admiral Colomb lias, on a previous uccasion, written snme rery admirable notcz and memorasda on the attack by cruizers of these same comuereial ports, and he has prored to us that some local defenees must be prorided for then. We must, in fact, hare what lias been rers properls called "the minimum of defence" both fised and floating for theso ports, and that, I think, is all that the War ofice desires and, at any rate, all that the War Oflice can get from the country. Unless we have a sinall amount of fixed defences at our comucreial harbours we may hare our commercial flects burnt at their anchorages. I really trust that what the gallant Admiral lass said against fired defenecs may not go the round of the Prese, nor cause the public to object to, and the influential people in the commercial ports to come forward and decrs tho use of the modcrate annount of fiscd defenses which we Enginecrs now desire to sec prorided for those ports. 
$\Delta$ dniral Bors : We hare listened to one of the most important lectures and ono of the longest discussions that I recollect in this theatre. My remark 3 will be rery short. Admiral Colomb prefaced.his pnper bs nsting menibers to "giro it him loot," and I think to a certain estent ho has had it pretty hot from somo of the epcakers. He refers to history to prore his case, but I think history is not altogether on lis side. If instead of going back 300 years he had gone back as long as history records, he would find that there actually hasl been inrasions and descents on the United lingdom to thic number of screnty, and forts-two since the commence. ment of the tenth century. It is our duty to prerent tho possibility of number forty-three. We hare liad a good many opinions here from naral Oficers on this side of the Ciranncl on this mattcr of blockading the cneruy's tect; I think naral Oficers on the otlicr side of the Channel hare also an opinion, and i heard it stated lately that when the subject of our blockading their ileets in their liarbours with our flect, as it now exists, mas mentioned, it was receired with a doubtful smile. 'Thes thimk and tlics renture to state that with a rers little belp it is not im. possible that they might be able to drire our ships into our harbours and blockade them there. 'That is not a position to be enntemplated with ang eatisfaction. I must say I ngree with Allmiral Colomb, ns many others do, in his endeavours and his adrocace to inercasc the Bcet, and in such nuwbers as are considered requisite for the duties which it ought to do; but if he proposes to leave our commercial harbours and our arsenals and our ports generally without ang land defenco whatcrer, I cannot agree with him.

Mir. R. N. Pesnose Fitzgxisd, MI.P.: Would Sir Lintorn Simmon, who has giren us the most rital important statistics I hare crer heard on this question, kindly, if possible, add to them the statistics of the ralue of the food supply im. ported by sca into this country in 1803, and the raluo of tho food supply thint is imported into this country in 1859 or 1859 ? I ask it purcly for uso possibly in another place, $a s$ it rould be most valuable information.

'rofessor LacGuton: At thiz late hour I shall limit mysclf to rery few reniarks. I had meant to touch on the general subject of the lecture, but my opinion having been so fully expressed, more especially by Sir John Colomb, that there is scarcely room for me to saj anjthing morc, but on eome of the historical allusions made by the lecturer and other gentlenien, $n$ few words from me will, perhaps, not bo altogether out of place. Aduniral Bors said that this country has been iuraded forty-two times; and Sir Jolın Hay pointed out that in past times the country was eucessfully inraded by William the Conqueror, by William III, and by Henry Tulor. This last can ecaicely be counted ns an inrasion; but in anj casc, there was no fleet to oppose it; so also with regard to the instances referred to by Admiral Bors. But as to Willian the Conqueror's inrasion, Sir Jolin Haj has orcrlooked the fact it was delajed in Normandy for thece montlis after the army was reads; it was waiting-we are told-for a south-west wind; a south-west wind in the Channel in July, August, and September! The statement is absurd. It ras waiting because the Fuglish had a porerful flect at the Isle of Wight; und until that llect was broken up, the Duke of Nornandy could not risk the passage; when the feet was no longer there, he crossed and effected the conquest. William III's landing can scarcely be spoben of as a forcign invasion : his fleet was commanded by an English Admiril, Ferbert; and the English flect which ras asscmbled at tho Gunflect to oppose him had been won orer to his causc. No opposition was offered by it, and the l'rince of Orange had rcason to beliere that none would bo offered. I think Admiral Culomb's argument is a rery strong onc; that with the Nary in command of the sea an cnemy cannot undertote the operation of an in. rasion. It secmed to une in the course of the discussion that many of tho epeakers hare not realized the power of a flect in a flanking position, threatcaing to act on the rear, or to interrupt the operation of linding, on which Admiral Colomb has laid such stress. It is, as $A$ dniral Colomb his pointed out, a matter of historical fact, a matter of common experience extending through all ages-not a matter of the last fifty ycars, bul from the beginiíng of history - that no commander, if lie is wise, will undertate a territorial attask as long as his operations mag be interrupted by a flect eren considerably weaker than his own. Admiral Colomb mentioned two distinct cases in which a commander had violated this principle. 
IIe might hare gone further, there hare been otbers. There ras one as far back as 1217, when the Frencle flect, in great force, bringing rcinforcements to the Dauphin in England, ignored a companatircly small force at Dorer. What was the result? This emall force fell on the rear of the French Acet, and annililated - it, off Sandwich, simply because it caught the French flect in the most unfarourable position in which a ficet can be taken. Another instance occurred in 1759 . The lapse of more than 500 years, and the cnormous changes in the details of naral mar, Jnd made no difference in this fundamental principle of naral stratery. Mr. de Conllans, sailing from lbrest, altempted to confluct the operation of takiner on bourd an army, and flat while such an enemy us Inwbe was frec to act on his rear. . Ianke miade a hawk-lilic swomp, anel demolished him. 'llese are two instances. I au not sure that the liattle of the Nile was not another. It ans rate it is certain if by possibility Nolson had lad with him the frigites that he ought to hare bad, if he had had one ounce less energy than he aciuilly did hare, the fircnch tect would hare becn canght in the idcal position that Adwiral Colomb has pointed out, and have been male an example of to all age's. It was pretty well so as it was, but it might hise been much more.

Cipptain FirzGLisd: Is not that an example of territorial attock when the attacking licet liacl not command of the sea?

I'rofesor Jistantox: 'The French flect vas destroset.

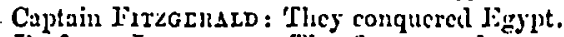

P'rofesol Lacgntor: The flect was destrosed, the communications were cut, and the army was left in a mess from which not cren the genius of Bonaparte could extricate it. There is just onc more word I liave to say. A good deal has been said about Gibrultar. It has been pointed out that the fortifications rendered its defence possible in the war of American Independence; that without the fortifiea. tions it could not hare been held. It scems to me that it would hare been a good thing for us if there liad becn no fortifications, if the enemy hial been free to come and go. What possible good was Gibrultar to us for the four years the Spaniards were besieging it, from 1779 to 17s3? Some 6,000 or 7,000 soldiers were shut up. there, and the flect was obliged at all risks to reliere them. What was the use of it? It was defending nothing; no property, no roufe; we had no interests in the Mediteriancan, absolutely nouc, but bccausc the strong fortwes was there, and it would be dangerous in the hands of an cnemy, we were obliged to retain it. For that we sacrificed our American Colonies. In 1781, when Durbs was fitting out a large flect to reliere Gibraltar, tlac bloskade of which $v$ as maintained by the Spanish flect, Je Gmsso was at Brest fitting out a powerful lleet for the West Inclies. Darbj would not interfere witl Do Grasse, for f(ar that if lie ansde any attempl to do so, I)c Grasse would go south and join Corlova, and the two flects, the French and Spanisl: combincd, miglat precent the rclief of Gibraltir. He, therefore, drew back and waited at Corb fill hic understood De Grusse liad sailed for the IV'st Indies, and thence to tl:c const of North America. Tlic setion with Grares off the Clesajeake, the surrender of Commallis, and the loss of the Americau Colonies were the direct resuts.

Admiral Corous, in reply, said : Some of the speahers hare pointed out that possibly my chief object in reading a paper, which eertainly secus to hare presented numerous anomalics to the audience, was laising a discussion. Fow, with the lelp of our gallant Clataman, whose mame was sulficient to bring the large audience together, we hare hnd, I think, one of the very best discussions on anj paper which has been read in this thentre. For my own part, the only fault I liave to find with the diseussion is that 1 have not been lit hard cuougl-perlaps I should not say hard enough, but close cnough. That my friendly adrersarics hare not got out their daggers and their fists and come at me, but thes hare stood far away with their long lances, or with weapons of still greater ringe. What I mean is, we have been discussing a purely scientific paper, with the title "The Relations between Local Fortifications and a Moring Nary,": and yet I am satisfed that when we come to reat the discussion eide by side wifh the paper liercafter, wo slanll sec that we have said rery very little indced concerning those "relntions." I must instance in earing that, and I lo it of course with great dididevee, what Lord Carmarron said, is showing that truls the points of the paper hare seldom been grosped bs the audience. 
It has happened to me before this to read a paper licre, to hare it warmly denouncel by a brother Oflicer, and to find that Oficer saying to me after sone little tine, when I hitd asked him to re-read the paper, that he liad re-read it, not once but trice, and that a reil had been remored from his mind, and that he san the position I had put before him in an nltogether new light. Sow, when you hare to put a great deal into an liour's paper, your words hare to be so vers accurate that they will not bear paraphrise. 'The moment you come to paraphrase you are nearly sure to go wrong. Mrost of the spealiers hare mentalls panalirased a grcit many of my scntences and misapprehended them. IBut, coming bock to what I said nbout the instance of Iorul Carnarron showing low the real points of tle paper hive not been grasped, we must remind ourselve's that Lord Camarron probably bas thought of those things more than any of us bere present. As the Chairman of the Royal Commission, he must lave had the wliole subject very much before him. What is the gist of my yaper? I took as my tests certain theses which were put forward by a previous lecturer. What J.ord Cariturron hats clone, if jou come to read his speccli carcfully jou will see, is to reassert all those theses which I was discussing, but without considering it neccssary to support his re-assertion by correcting a single one of my historicul referenees or at single one of my illustritions. IIc suid, towarls the close of his specel, that the object of fortifications mas first to free the Nary; secondly, to preserve slipss so as to cnable them to be repuired; thirdly, to slyply conl to the ships; and fouthly, to deter the cnemy's cruizers. Now thesc are exactly the four points that Cajt:ain Stone put forward, and those are cxictly the four joints that I used, historical and hypothetical illustrations, to cocsbat, in order that we here, a naral and military audience, might get to the bottom of them and sce whether it was actually so. Sir Lothim Nicholson flattered me in the strongest way when he said that this paper that I wrote would hare a great induence on public opinion. Well, I do not deny that it may hare a great influence on public opinion, but what Sir Lothian Nicholson said was that what would gire it that intluence would be the fact that it was read by un Oflicer like mysclf. Now I am quite certain of this, that ans little inlluence I night liare does not come in anr way from me personalls, it councs siuply from the facts that I collect and put forward; and if it be the case that this piaper is to hiare an effect upon public opinion, it nill hare it because I hare endearoured, cren as un ndrocite, to put forward the truth. It is perfectlr truo that for the purpose of discussion I liare put what appears to me to be the logical truth rery clistinetly, and as closcly as 1 can, and also in such a way as to excite the opposition which I am lappy to say has becu excited. But I am sure of this, that the real discussion on this pajer will take place hereafter. We have only started it now. IFe have to recollect this. And here again I must refer to what Sir Lothian Nicholson said. He pointed out that it would be an evil if my paper appeared in the press in anything like a complete state, and that the discussion in opposition to it, which he rightly judged would be in opposition to it, should appear in a garbled state. IBut all that has becn said in opposition to me has been said year alter year and month after month for 23, 21, or 25 vears stendily. It is the first time, as far as I lnow, that the general rien of the relative functions of fortifications and the Navy has ever been ehallenget. Why did it become to me so important to challenge it when I hearil the opposite vicr clistinctly stated by Captain Stone in this Institution? It is because, unless the druy and Nary come together in this way and discuss these points, where our functions are likely to orerlap, and arrive at something like conclusions about them, we are doing what Sir Lintorn Simmons said we were doincr, what I myself fecl wu are doing rers often, that is, haring a sort of gaume of pulles-liaules with tho Chancellor of the İchequer. But I am so satisfied with the cordial relations between the two Serrises as to belicre that we waut nothing to bring us together. and to make us sce our parts perfectly clearly but the continuation of the sort of discussion we hare had licre. Erery one of us, I should think, nust hare had some new thoughts, some new suggestions, as to how far the Jarj gocs in these matters, and how far the Aruyg gocs; and what would happen to the Irmy if the fortification bills went up and the moring navy bills went domn, ind rice versa. If the Arng were relicred from the pressure which now lies upon it-and it is a great prcesure that providing licury garrisons for licars works-hor could it bo adran. 
taged? If it were ascertained that the Nars could do tho things which Colonel Murice told us of, and that naral people all bnew it? Colonel Aaurice told us, and this is another reason why my paper was read-what is absolutels the fact, that the Nars stcadily repudiates, and has for jears repudinted, this defenec ques. tion, and it las distinctly eaid: "We will not have anything to do with places like Singajore, or Aden, or Colombo, or the Cape : we will wash our hands elear of it. It is your business in the $\Delta$ rmy to do all this, our business is elsewhere." Now that point in the nawal mind is one of my principal objects of attack. I do not think that it is true: I clo not think it possible that the Narg, whinterer it mas haro dowe in former days, can slabe from its sloulders this question of the defence of the ports. Ms gallant fricnd Coloncl Steward, spealing of the commercial ports, Eaid that I thought they could not be defended by fortifications, but I lave nerer caicl that, and hitre nerer thought that of the ports themsclves, only of the shipping frequenting the ports. If you csamine my paper gou will sec that all through it I nelmit the plain pacnt fisct tbat ans port which you can close, nny port that jou do not care about kecping your communications open with, ean be macle secure with fortifications; and you can make it so secure that, like the hall-doos of jour house, it is the rery last place that the burglar will think of going to. But the whole point of mj paper is the difference betticen a port which you can close and a port which gou must becp open. The point of it is that with regarcl to the coaling stations, thesc ports are, crers onc of them (I mas cxcept, perhaps, Bcrmuda), ports that the siry must in some way keep open, because from them and to them flors the life-blood of the Ewpire. It lias been censtantly said by uing speakers that I recommend the learing of the ports defenceless : the ide: of learing the ports defenceless never crosscd niy simel. But I s.ay that ports are defended-and that history shows it distinetly donn to the other diay-from heary uttacls by the threat of tliesc attacks bcing interrupted from the sca, as was so execllentle put by l'rofessor Iaughiston ; tiut the cntry and exit to them must be protected by a naral force, a floating force, a moring force, and cannot be protected by ansthing that is fised. $A s$ it is necessary for you to proride this moving force, it then becomes a question whether beluind that moring force it is necessary to go to ans rery great expense in the matter of ficd fortilications, submarine mincs, and what not. The mistaken point that most of the epeakers have had in their minds is that where there were no fortifications there was nothing. Jut that has not been in my mind, and that las nerer been in my brother's mind, who, as far as I knom, was the earliest of all to raise the question of the defence of the conling stations. If you will read his first prauphlet on the "I) fence of our Coumerec," published, I think, in 1867, you will note that he was always thinking of open ports bept open by maval forec, and that he nerer had the slightest notion of heary fortifications. He wanted a good garrison; he wanted special port clefence rcssels, and there in his diagram rou hare these port defence resels, not defending the place itself, but the surrouridings of the place, becping the communications with it open, guarding the coumerec whero it was concentrated from the attacks which were most likely to be made upon it. Ind so you must recollect that when speaking of fortifications not being effective, I mean thes are not effective for a jort nhich must be kept open, becuuse they will not keep a port open. I am sure tliat erery military man will agree with we tlere; fortificitions aloric will not kecp a purt open. If you can nflori to allow a port to be closed, all right, go on, syend what you like; but if it is a jort you must heep open, we ouglit to go to work to kecp that port open to proride the necessary force for kecping it open, and I think it stauds to reason that if we keep the port open, we defend it. I camnot sce that there is auything on the other side. If sou provide a naral force suticient to bep the port open, the cnemy cumnot touch that pert. I an giviug, of course, but a general reply. The time has gone on so long. that I nu sure those speakers who would like to be answered ecparstely will escuse ne from going closely into what they hare said, and I think there is the less reasou for me to do that because the paper will be found, if ron study it closely (for I do mysclf the credit of Eaying that it is most carcfully written), and go into it aide by side with the criticisens that lase been offered, there will be a greal deal wore agreement with me than there appears to bo at the present moment. At the eame time, I must admit, as I adnitted at the 
beginning, that for the purposo of raising diecussion I hare pushed the theorctical scientile question, I think, perliaps as far as I cau push it. The practical outcomo of it is a matter that I haro not touched upon in the paper, but that is chichy what las been discussed in this theatre, wistaking, I think, the teudency of the paper. I regret, of course, that the scientific question has not been more thoroughly discussed than it has been, but I feel sure that the discussion will go on in our mincls, and that we shall come to some definito conclusions about it. Fou must recollect that such a paper as this has been in my mind erer eince the Estimates were mored for last year, when there was a rote on a loan of $3,000,000$ l. for fortifications side b5 side with $\mathfrak{a}$ reduction in the Naral Fistimates of $900,000 l$. That, I may say, was the moring epirit behind me, and I do beliere that if this audienco vere called upon to pronounce upon a similar proposal now, it would not bo carricd. There is just one question which I might mention. It was put forward by sir Joln Stokes, the rery old argument that as the Nars was weak, and as the Narg could not at the present woment hare the command of the sea which we desire for it, we had better go and epend the money on fortifications on that understanding. The chief reason adduced why we should take that course appeared to be the question of tine. It is held that we could provide fortifications more quichly than we could the necessary uaral force. I altogether differ from that. MIs impression is, if it is a question of time for the defence of the roaling etations, we can more realily get merchant ships fitted up ritl whaterer guns can be had, than we can mount the same gums on land. And these guns, so mounted, are not only competent to protect the port, but to protect the shipping which make the port. That is the artument. I do not nican to sas how that is. I must thank jou, Sir, rers licartily, for taling the chair during the discussion of a naral subject of this hind. I gire wysclf credit for polics in resking sou, Sir Frederick Stephenson, to tale the cliair. I felt this, that if you took tho chair and read my paper before taking it, which you did, it would be certain that I should say nothing in that paper which would be liurtful to the feclings of the sister Serrice. I knew very well that if you were in the chair me should not get liotter than we need get, and I felt that jour presence in tho chair mould bring together a large military audience, and would gire a guarantec that I was not, as some speakers do really scem to think, putting the Nars against the Army, which is the rers lost thouglet in my mind. What $I$ hare said in tie paper, and what $I$ must repeat nor, is, that I am afraid that if the Sary and the Iring do not join together in theso discussions and come to definite conclusions as to their relative positions under the changed circumstances of warfare, a great deal of mones will be spent, and, as tho public eay, thes will get nothing for it. But if the Nary und the Army can thus settle what their functions are to be, cren the Jlinistry of Defence, which Sir Iintorn Simmong is so ansious to hare, would become not a necessity, for we should hare ectlled all the points which the Jinister of Defence could settle, before he was appointed to his post.

The Cirainsis: Gentlemen, at this late hour of the crening I shall confine myself to rery few remurks indece. In the first place, I think the gallant Adruiral may be satisfied on one inportant point, and that is the rital importanes which we all of us attach to the supremacy and the most thorough and complete eficiency of the Nary. I think.that is a point upon which we all agree, and I necd lardly satisfy his mind upon that point. I only wisl that ono half this fecling were preralent throughout the country at large, which is awaking at lost, we nust all be glacl to sce, from the indifferenec, not to say the apathy, with which it has ricucd the important and vital question of the national defenecs of the country. There is one other point upon which I hope the gallaut ddmiral mas also be satisfied, and that is that the requirements of the Arms for carrsing out theso national defences are not likely, I should hope, to interfere with the claims which the Nary mas mato upon the public pursc. The NarJ, of coursc, are entitled, and I hope thes will get it, to the first and the fullest consideration; but there are also some points upon which I think also the Arms was lare sume slight claim as well. Gentlemen, with regard to the reply the gallant ddmiral has made, I think it maj possibly qualify to a certain ertent the impressions that eristed in the minds of those who spoke with regard to the subject of his lecture, for he now tells us that he is perfectly aliro to the neccssity of a certain amount of defence to our ports, our arsenals, and our 
coaling stationz.' Now that, I confess, I understood kas the rery bone of contention, it is the rery subject I understood of his lecture; liowerer, I am rery glad to find by this expression of his opinion now in lis reply that we are all at one upon this. It is unnecessary alnost to dilate upon the absolute importanec of the defence of our arsenals, our ports, our coaling stations, and, I should like also to add, of the principal of our commercial ports, certainly towards their sea fronts. Witle regard to the conling stations, by putting them in a proper state of defence, we surcly beep the Nary from the necessity of protecting them to a rery considerable extent, and we gire the Nary thereby a freer hand to act upon our lines of communication, instead of detaching certain rcssels to hang abont these coaling stations, which for the time being are perfectly capable, or should be made perfectly capable, of defending themselres. I think, howerer, in this respect there will be no wish to wake any claim upon those funds, which, I liope, will bo almost, if not entirely, deroted to the cliciencs of the Nars. I hare unly one thing wore to do, and that is to ask rou to allow me to conres to the gallant Admiral our very sincere thanks for the able manner in which le has drawn up his paper. I think wo are excessircly indebted to lim for it. I think also we are still further indebted to him for this, that in bringing forward his paper, he las done so in the most dieinterested und brondminded spirit. IIe has wished under no circumst ances to cram his ricws down our throats; on the contrary, his object his been to elicit and draw forth the freest possible discussion upon all points, and I think, consiclering the rery full attendance which he has liad at his lecture, and at this adjourned discussion, he mas be fully satisfied that his wish has been thoronglily carried out. 